\title{
Mechanical behaviour of unsaturated undisturbed black volcanic ash soil under static and cyclic loading
}

\author{
Okri Asfino Putra ${ }^{1, *}$, Noriyuki Yasufuku ${ }^{1}$, Ryohei Ishikura $^{1}$, Adel Alowaisy $^{1}$ and Yuko Kawaguchi ${ }^{2}$ \\ ${ }^{1}$ Department of Civil and Structural Engineering, Kyushu University, 744 Motooka, Nishi-ku, Fukuoka 819-0395, Japan \\ ${ }^{2}$ West Nippon Expressway Company Limited, 1-6-20 Dojima, Kita-ku, Osaka City, Japan
}

\begin{abstract}
The mechanical behaviour of unsaturated undisturbed black volcanic ash soils was investigated using a constant volume direct shear apparatus. A series of static and cyclic tests were conducted under unsaturated and saturated samples. The cyclic test under two patterns were adopted. First type of pattern, cyclic one-sided shearing was applied. For the second type, two-sided shearing was conducted. For further understanding of the chemical content and microstructure, X-Ray Fluorescence analysis (XRF) and Scanning Electron Microscope (SEM) were evaluated. It was found that, under static shearing, the unsaturated sample exhibits a higher apparent cohesion and friction angle in comparison to the saturated sample. The normalized vertical stress under one-sided cyclic shearing in both overconsolidated and normally consolidated samples rapidly reduced at the beginning of shearing. This might be attributed to increase of the pore water pressure during shearing. Furthermore, there is a significant difference between the normalized shear stress under cyclic onesided and two-sided shearing. For the two-sided cyclic shearing test, the normalized shear stress value is higher than the one-sided cyclic shearing test. In addition, the normalized shear stress under unsaturated condition is significantly larger. This can be related to the suction forces to the total strength of soils. The main chemical content of the black volcanic ash soil is allophane. Further, the microstructure of the black volcanic ash changes due to shearing. For the overconsolidated sample, particles of soil more severe damage than normally consolidated sample.
\end{abstract}

\section{Introduction}

Black volcanic ash soil, known as Kuro-boku soil in Japan, is a problematic type of soil [1,2]. Kuro-boku (organic cohesive volcanic ash soil) is typical allophaneous volcanic ash soil which has high natural moisture content varying from 65-140\% [3]. Distribution of black volcanic ash soil covers approximately $31 \%$ of the total area of Japan, mainly within the volcanic zones [4].

Black volcanic ash soils are generally found near the slope surfaces above the groundwater table which is generally unsaturated. The unsaturated zone is part of the subsurface attending from the ground surface and the groundwater. The soil within this zone imposes a degree of saturation less than $100 \%$.

The soils under unsaturated condition have higher resistance in comparison with the saturated condition. But under heavy rainfall events, the pore water pressure increases leading to loss of shear strength and slope instability may occur.

In 2016, Kumamoto earthquake triggered many slope failures around the Aso area. In general, the slope surface in the Aso area consists of volcanic ash soil and commonly overconsolidated due to the environmental effects. The black volcanic ash soils and orange-colored pumice deposits are the most common types of soils that experienced failure in the Aso area. The key factor in slope failures was to be the shear strength of the volcanic soils before and after the earthquake [5].

Many researchers have studied the volcanic ash soil in Kumamoto slope failures, especially the orange-colored pumice [6-9]. They investigated the shear strength by a series of static and cyclic triaxial tests. However, small attention was given to the shear strength and characteristic of the black volcanic ash soil.

In this paper, the shear strength and characteristic of black volcanic ash soil was evaluated. A series of static and cyclic tests using the constant volume direct shear box were performed. Also, for further understanding of the microstructure and chemical content of the black volcanic ash soil, X-Ray Fluorescence analysis (XRF) and Scanning Electron Microscope (SEM) has been done.

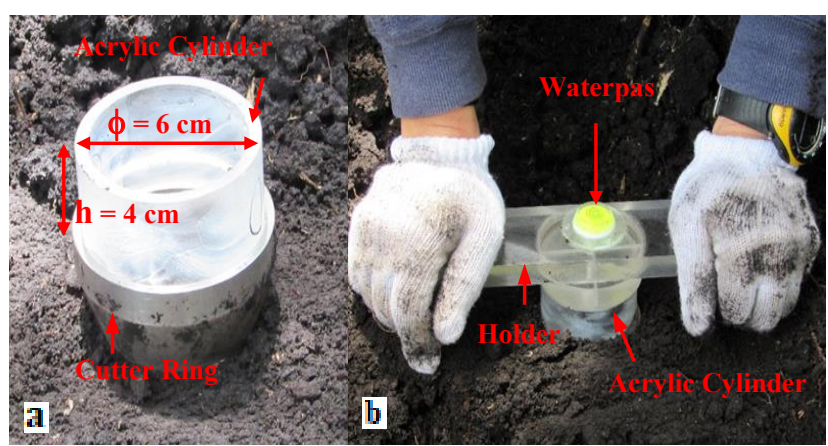

Fig. 1. Sampling setup. a) Acrylic cylinder b) Sampling.

* Corresponding author: okriasfino27@gmail.com 
In order to enhance understanding of the black volcanic ash soil behaviour same as natural condition, undisturbed samples were collected and focused on overconsolidated area. Furthermore, to consider the effect of changing the moisture content under precipitation events, saturated samples were tested.

\section{Methodology and Materials}

\subsection{Sampling methodology}

The newly developed undisturbed sampling methodology for the black volcanic ash soil is illustrated in Figure 1a. Sampling was carried out using $6 \mathrm{~cm}$ in diameter and 4 $\mathrm{cm}$ in height acrylic cylindrical moulds. Before sampling, the inner of the acrylic mould and the cutter ring were lubricated using grease oil. In order to avoid plants and roots, sample were collected $10-20 \mathrm{~cm}$ below the ground surface. The mould attached to the cutter ring were pushed using a plate into the ground as illustrated in Figure $1 \mathrm{~b}$. After that the samples surfaces were trim using spatula. In order to keep the moisture content same as the natural condition, samples were kept and covered by plastic bags.

\subsection{Materials and sampling locations}

Tests were conducted using undisturbed samples. After Kumamato earthquake 2016 many slope failures around Aso area occurred. Samples were collected at the middle and the top of the slope failure zone at the boundaries as illustrated in Figure 2. Samples were collected $1.5 \mathrm{~m}$, from the original surface next to the failures zone boundaries and the cross-section mainly showed the black volcanic ash.

The physical properties of the black volcanic ash are listed in Table 1. It can be seen the organic matter content range from $22.9 \%-28.2 \%$. The particle size distribution curve is shown in Figure 3. The median grain size $\mathrm{D}_{50}$ is approximately $0.012 \mathrm{~mm}$. Based on that, the black volcanic ash soil can be classified as volcanic cohesive soil type II $\left(\mathrm{VH}_{2}\right)$ according to the JGS standards.

The consolidation test results of the black volcanic ash under various degree of saturation as indicated in Figure 4. The yield stress in the unsaturated undisturbed sample was $105 \mathrm{kN} / \mathrm{m}^{2}$ in average. Based on the consolidation test results, the black volcanic ash used in this research is considered as overconsolidated soil. Where the sampling depth is around $1.5 \mathrm{~m}$, thus overburden pressure less than $105 \mathrm{kPa}$.

\subsection{Methodology}

In order to examine the shear strength properties of the black volcanic ash soil, a series of constant volume direct shear box tests were carried out considering both unsaturated and saturated samples. During shearing, the specimen volume was maintained constant or not allowed to change in volume. A schematic diagram of direct shear box test is illustrated in Figure 5. The box is divided into upper and lower parts. While the bottom fixed and the top movable. $2 \mathrm{~cm}$ in height circular sample were prepared for test. In a static test for overconsolidated sample, 10 and $50 \mathrm{kPa}$ vertical stress was applied. On the other hand, for normally consolidated sample $200 \mathrm{kPa}$ vertical stress was adopted. Before the shearing start, specimens were consolidated under the designated vertical stress each condition for 1 hour. Then, sheared with the undrained condition up to $7 \mathrm{~mm}$ at a shear rate of $0.2 \mathrm{~mm} / \mathrm{min}$ according to the JGS standards.

In order to examine the shear strength of the black volcanic ash soil under the earthquake shakes, a series of cyclic direct shear box test using both unsaturated and saturated samples was carried out. The cyclic test under two pattern with displacement $1 \mathrm{~mm}$ were adopted. First type of pattern, cyclic one-sided shearing was applied. Where shearing was started from $0.5 \mathrm{~mm}$ to $1 \mathrm{~mm}$, from $1 \mathrm{~mm}$ moving back to $0 \mathrm{~mm}$ and again to $0.5 \mathrm{~mm}$. The total of displacement for one cycle was $2 \mathrm{~mm}$. On the other hand, for the second type of pattern two-sided shearing was conducted. Where shearing was started from $0 \mathrm{~mm}$ to $0.5 \mathrm{~mm}$, then from $0.5 \mathrm{~mm}$ moving back to -0.5 $\mathrm{mm}$ and again to $0 \mathrm{~mm}$. The total of displacement for one cycle was also $2 \mathrm{~mm}$. For each pattern, a total number of cyclic was 10 times. Then, the shearing was terminated when the displacement reached $7 \mathrm{~mm}$. Based on that, the cumulative displacement for both pattern for one times test was $27 \mathrm{~mm}$. A schematic diagram adopted pattern is shown Figure 6 . The $50 \mathrm{kPa}$ vertical stress was applied for the overconsolidated sample and $200 \mathrm{kPa}$ for the normally consolidated sample was used. The initial suction before shearing [10] is shown in Table 2.

Table 1. Pyshical properties of the black volcanic ash.

\begin{tabular}{|cc|c|}
\hline \multicolumn{2}{|c|}{ Physical properties } & Black volcanic ash \\
\hline Water content & $(\%)$ & $111-159$ \\
\hline Dry density, $\rho_{\mathrm{d}} \quad\left(\mathrm{g} / \mathrm{cm}^{3}\right)$ & $0.56-0.58$ \\
\hline Wet density, $\rho_{\mathrm{t}} \quad\left(\mathrm{g} / \mathrm{cm}^{3}\right)$ & $1.18-1.25$ \\
\hline Spesific gravity & $2.28-2.34$ \\
\hline Liquid limit & $(\%)$ & $154-214$ \\
\hline Plastic limit & $(\%)$ & $112-139$ \\
\hline Organic matter & $(\%)$ & $22.9-28.2$ \\
\hline
\end{tabular}

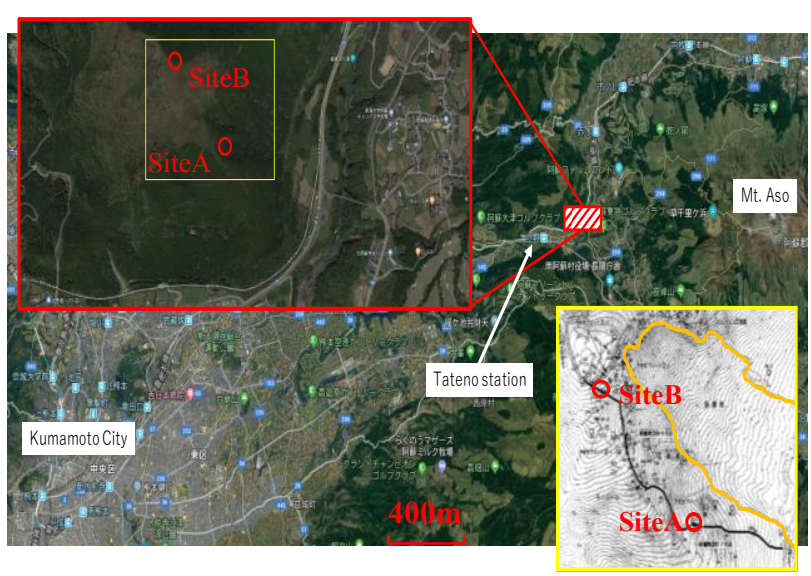

Fig. 2. Sampling location of the black volcanic ash. 


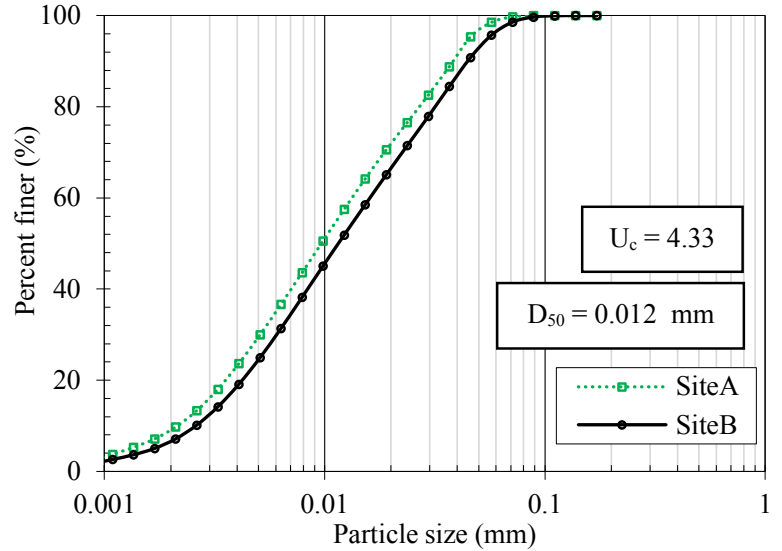

Fig. 3. Particle size distribution of the black volcanic ash.

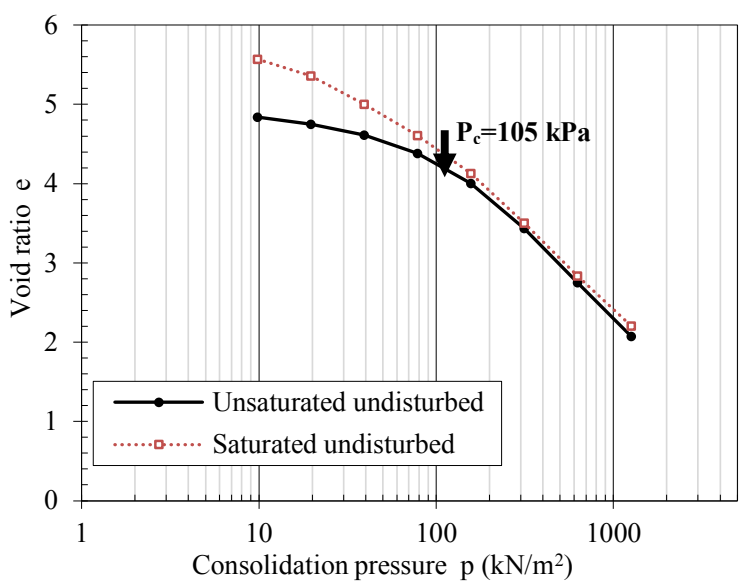

Fig. 4. Consolidation test of the black volcanic ash.

\section{Test results and discussion}

\subsection{Static shearing behaviour}

The relationship between the shear displacement and the shear stress is shown in Figure 7. It can be seen in unsaturated condition, for the normally consolidated sample the shear stress converges to a constant value with a shear displacement of $1.5 \mathrm{~mm}$. While, for the overconsolidated sample, the shear stress dramatically increases and converges to a constant value at shear displacement about $0.5 \mathrm{~mm}$.

The relationship between the vertical and shear stress for the unsaturated and saturated sample is illustrated in Figure 8. It can be observed that for the normally consolidated condition, the vertical stress increases dramatically till achieving the peak shear stress. Then, slightly decreases regardless of the saturation condition. On the other hand, for the overconsolidated condition both vertical stress and shear stress increases without distinct peak value. The observed behaviour is similar to the clayey soil behaviour under undrained triaxial test [11]. For the overconsolidated condition, the monotonical increases in the vertical stress can be justified to be a result of the pore water pressure reduction under shearing. On the other hand, for the

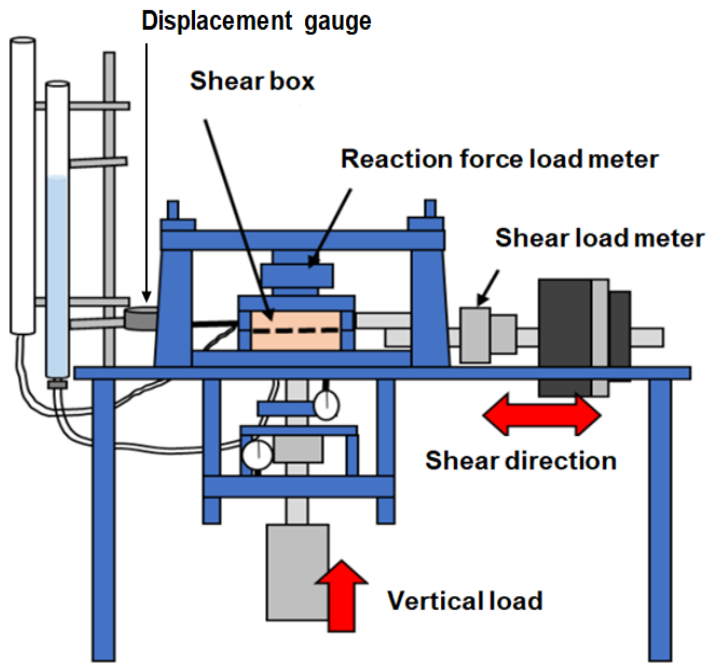

Fig. 5. Schematic diagram of direct shear box test.

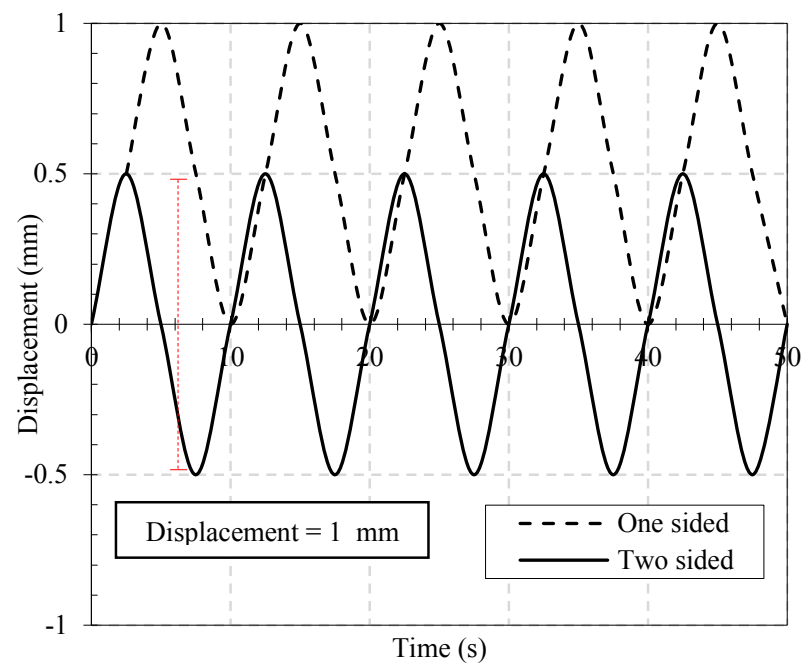

Fig. 6. Schematic of (one-sided and two-sided) cyclic loading.

Table 2. Test program for static and cyclic.

\begin{tabular}{|c|c|c|c|c|c|}
\hline $\begin{array}{c}\text { Test } \\
\text { ID }\end{array}$ & Sample & $\begin{array}{c}\text { Void } \\
\text { Ratio } \\
(\mathrm{e} 0)\end{array}$ & $\begin{array}{c}\mathrm{Sr}_{0} \\
(\%)\end{array}$ & $\begin{array}{c}\text { Initial } \\
\text { Suction* } \\
\left(\mathrm{kN} / \mathrm{m}^{2}\right)\end{array}$ & $\begin{array}{c}\text { Vertical } \\
\text { stress } \\
\left(\mathrm{kN} / \mathrm{m}^{2}\right)\end{array}$ \\
\hline Static test \\
\hline S01 & Unsaturated & 4.70 & 65.5 & 100 & 10 \\
\hline S02 & Unsaturated & 5.16 & 68.0 & 100 & 50 \\
\hline S03 & Unsaturated & 4.95 & 72.5 & 97 & 200 \\
\hline S04 & Saturated & 4.60 & 99.7 & 0.1 & 10 \\
\hline S05 & Saturated & 4.77 & 99.3 & 0.1 & 50 \\
\hline S06 & Saturated & 4.72 & 100 & 0.1 & 200 \\
\hline One-sided cyclic & \multicolumn{5}{|l|}{} \\
\hline C101 & Unsaturated & 4.03 & 67.8 & 100 & 50 \\
\hline C102 & Unsaturated & 4.01 & 69.5 & 100 & 200 \\
\hline C103 & Saturated & 4.41 & 99.5 & 0.1 & 50 \\
\hline C104 & Saturated & 4.45 & 96.8 & 0.2 & 200 \\
\hline Two-sided cyclic & & \multicolumn{5}{|l|}{} \\
\hline C201 & Unsaturated & 4.73 & 74.1 & 97 & 50 \\
\hline C202 & Unsaturated & 4.96 & 82.9 & 8 & 200 \\
\hline C203 & Saturated & 4.43 & 100 & 0.1 & 50 \\
\hline C204 & Saturated & 4.77 & 100 & 0.1 & 200 \\
\hline * Initial suction before shearing & \\
\hline
\end{tabular}

* Initial suction before shearing 
normally consolidated condition increases in the pore water pressure during shearing leads to decreasing of the vertical stress.

The apparent cohesion decreases from $24.6 \mathrm{kN} / \mathrm{m}^{2}$ under unsaturated condition to $13 \mathrm{kN} / \mathrm{m}^{2}$ for saturated condition. In addition the apparent friction angle slightly reduced from $35.5^{\circ}$ under unsaturated condition to $35.1^{\circ}$ for saturated condition. This tendency agrees very well with the results obtained by Bai and Atsumi [12, 13]. Finally it can be concluded that the shear strength strongly depend on soil water content, within translate into suction force which contributed to the total shear strength of the soil.

An empirical relationship of the overconsolidation ratio and the shear stress ratio was developed [14]. The relationship for the black volcanic ash soil is shown in Figure 9. The line represents an empirical model, while the scatter represents the experimental data. For OCR $=1$ the shear stress ratio was 0.55 , and the shear stress ratio increases as the increasing number of OCR. These obtained results are in well agreement with the kaolin clay behaviour [15].

\subsection{Cyclic shearing (one-sided and two-sided) behaviour}

The stress path of the cyclic one-sided shearing illustrated in Figure 10. It can be seen that the vertical stress significantly decreases in both overconsolidated and normally consolidated samples. Furthermore, in order to clearly understand the vertical stress reduction trend, the cumulative shear displacement and the normalized vertical stress were plotted as indicated in Figure 11. In general, the normalized vertical stress decreases by increasing the number of cyclic. When the normalized vertical stress decreases, it is mean affects the shear strength of soil [16]. The normalized vertical stress reduction might be attributed to increase of the pore water pressure during shearing. It must be noted that for both normally consolidated condition and overconsolidated condition, the normalized vertical stress exhibited similar reduction tendency and value. The normalized vertical stress decreases rapidly at the beginning of shearing. However, for the overconsolidated condition the normalized vertical stress decreases till reaching 0.65 . Excluding the saturated normally consolidated sample, all samples converge to almost constant normalized vertical stress ratio when reaching $12 \mathrm{~mm}$ the cumulative shear displacement. After reaching a total cumulative displacement $20 \mathrm{~mm}$, the shearing continue to $7 \mathrm{~mm}$ under static condition. It can be observed the normalized vertical stress significantly increases in the overconsolidated area but can not converge to the initial condition. On the other hand, in the normally consolidated area decreases till the end of shearing.

The relationship between the shear displacement and normalized shear stress in the overconsolidated area illustrated in Figure 12. There is a significant difference between cyclic one-sided and two-sided shearing. On the cyclic one-sided shearing the test results indicated that

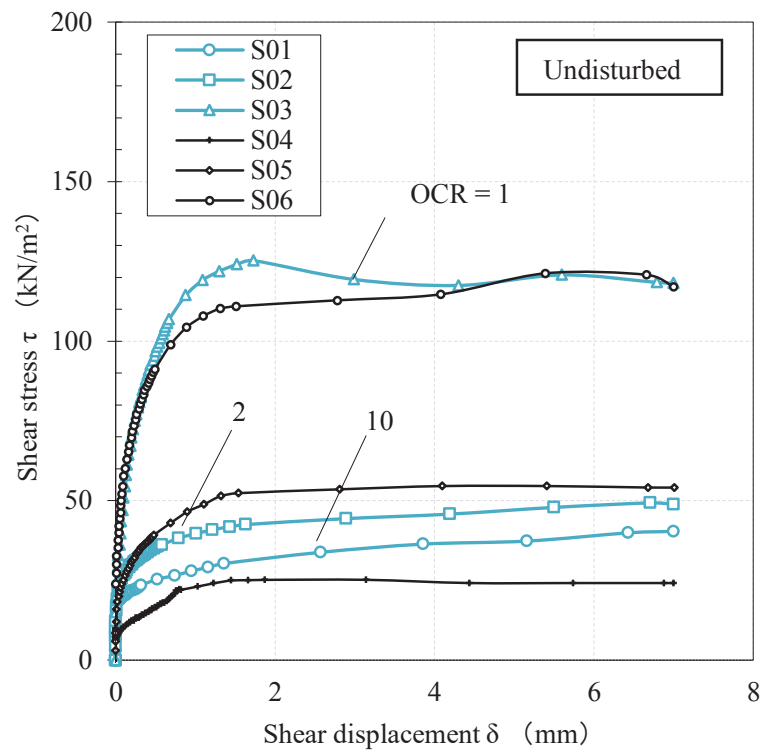

Fig.7. Relationship of shear stress and shear displacement

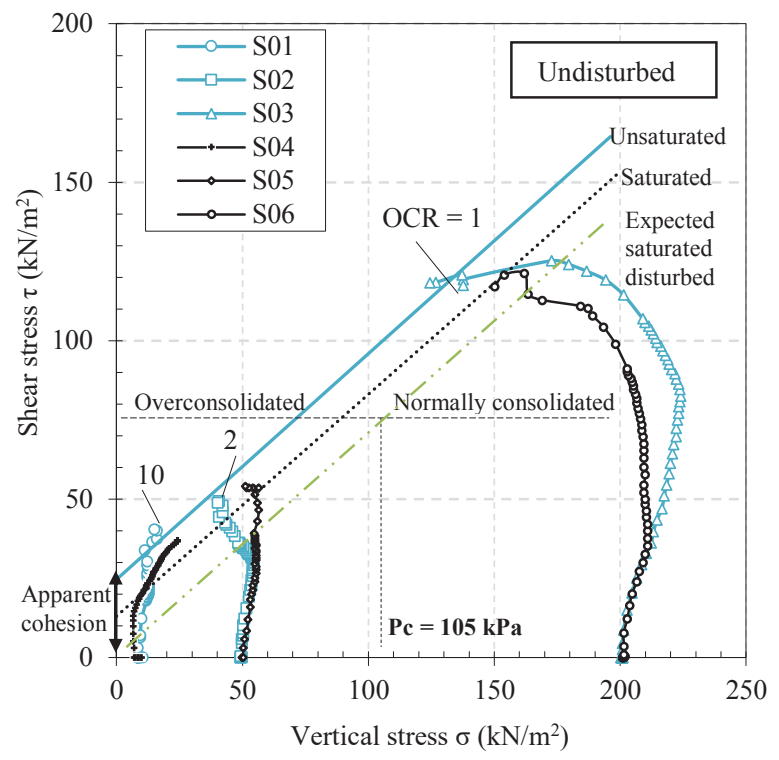

Fig. 8. Stress path static test unsaturated and saturated sample

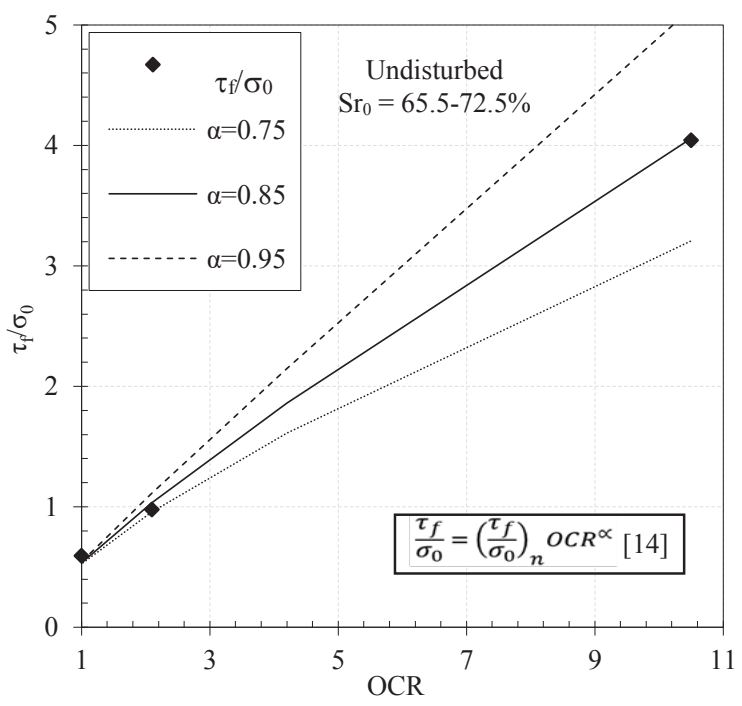

Fig. 9. Relationship of normalized shear stress at the end of shearing and overconsolidation ratio. 
the normalized shear stress decreases since the first of cyclic load. This can be attributed to reduction normalized vertical stress during shearing. These results are in well agreement with the Takanodai pumice under cyclic loading using direct shear box test [17]. On the other hand for the two-sided cyclic shearing test, the normalized shear stress value is higher than the one-sided cyclic shearing test. It can be observed that the normalized shear stress value increases with the increasing number of cyclic till reaching the maximum value at the $10^{\text {th }}$ cycles (final cycles). This might be justified to be a result increasing of frictional resistance of soils. The obtained results also are in good agreement with two-sided cyclic test direct shear box test results obtained by Cabalar [18] which reported that increasing of the normalized shear stress with the number of cycles for strain controlled test. Finally, It can be concluded that the cyclic shearing pattern and direction significantly affect the normalized vertical stress and shear stress of soil.

Furthermore, it can be observed the normalized shear stress of unsaturated condition, it is significantly larger. The obtained results are in good agreement with the shearing behaviour in the static shearing. This can be related to the suction forces to the total strength of soils.

\subsection{Chemical Content and Microstructure}

The chemical content of black volcanic ash soil results $\mathrm{SiO}_{2}, \mathrm{Al}_{2} \mathrm{O}_{3}, \mathrm{Fe}_{2} \mathrm{O}_{3}$ accounts for as high as about $93 \%$. It is known that these three are the main components of substances called allophane. Single particles of allophane are much smaller than other clay minerals and are extremely porous. In black volcanic ash soil, aggregate formation is further accumulated due to the bonding action of humus, therefore the soil structure become more porous. The chemical content of the black volcanic ash soil is listed in Table 3.

In order to assess the influence of the microstructure on the shear strength behaviour of black volcanic ash soil, Scanning Electron Microscopy (SEM) was carried out for the overconsolidated and normally consolidated samples. The SEM test results after the shearing are illustrated in Figure 13.

It can be seen that the microstructure of black volcanic ash soil significantly changes due to shearing. Where shearing changes the structure by breaking down the particles or the aggregate assemblage. For the overconsolidated sample, particles of soil more severe damage than the normally consolidated sample. It can be justified that the soil particles tend to move away from each other due to shearing. These results are in agreement with the final structure of soil after shearing affected by stress history [19].

Table 3. The chemical content of black volcanic ash soil

\begin{tabular}{|c|c|c|c|c|c|c|}
\hline $\begin{array}{c}\mathrm{SiO}_{2} \\
(\%)\end{array}$ & $\begin{array}{c}\mathrm{Al}_{2} \mathrm{O}_{3} \\
(\%)\end{array}$ & $\begin{array}{c}\mathrm{Fe}_{2} \mathrm{O}_{3} \\
(\%)\end{array}$ & $\begin{array}{c}\mathrm{CaO} \\
(\%)\end{array}$ & $\begin{array}{c}\mathrm{TiO}_{2} \\
(\%)\end{array}$ & $\begin{array}{c}\mathrm{K}_{2} \mathrm{O} \\
(\%)\end{array}$ & $\begin{array}{c}\mathrm{SO}_{3}, \\
\mathrm{P}_{2} \mathrm{O}_{5}, \mathrm{~V}_{2} \mathrm{O}_{5}, \\
\mathrm{~S}_{\mathrm{r}} \mathrm{O}_{2} \mathrm{Z}_{\mathrm{n}} \mathrm{O}, \\
\mathrm{C}_{\mathrm{r} 2} \mathrm{O}_{3} \\
\mathrm{MnO}, \mathrm{MgO}, \\
\mathrm{ZrO}_{2}, \mathrm{Br}(\%)\end{array}$ \\
\hline 50.2 & 28.7 & 14.4 & 2.1 & 1.8 & 1.0 & 1.0 \\
\hline
\end{tabular}

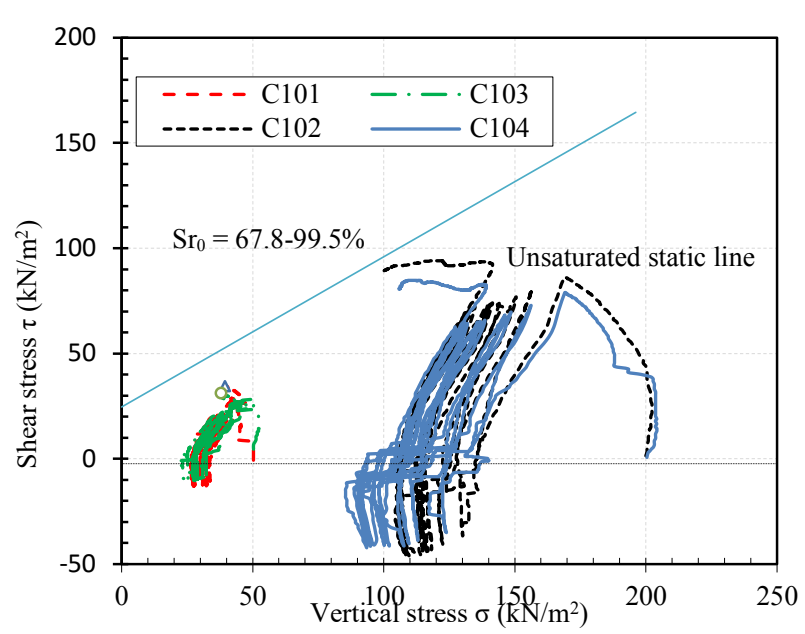

Fig. 10. Stress path of cyclic one-sided shearing under constant volume test

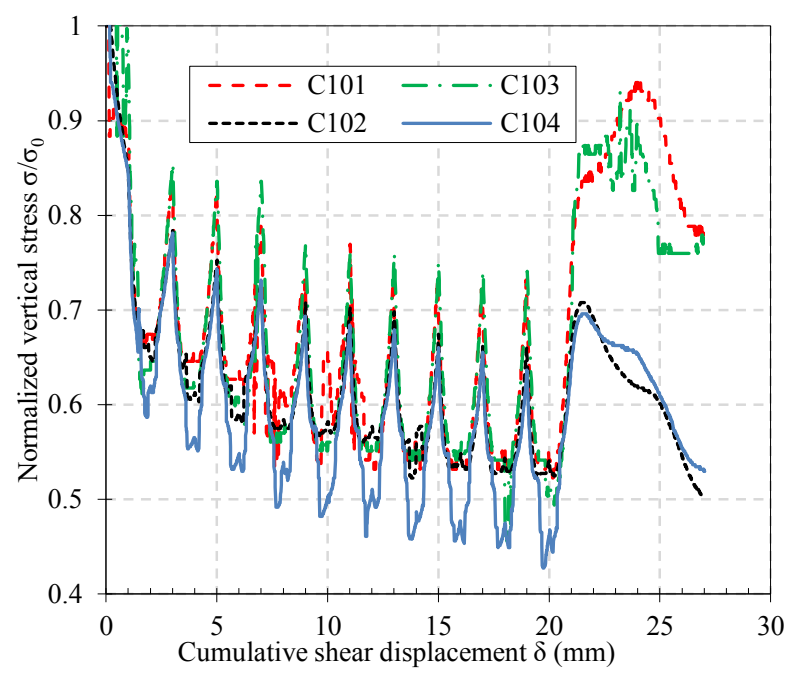

Fig. 11. Relationship between the vertical stress ratio and cumulative shear displacement one-sided shearing

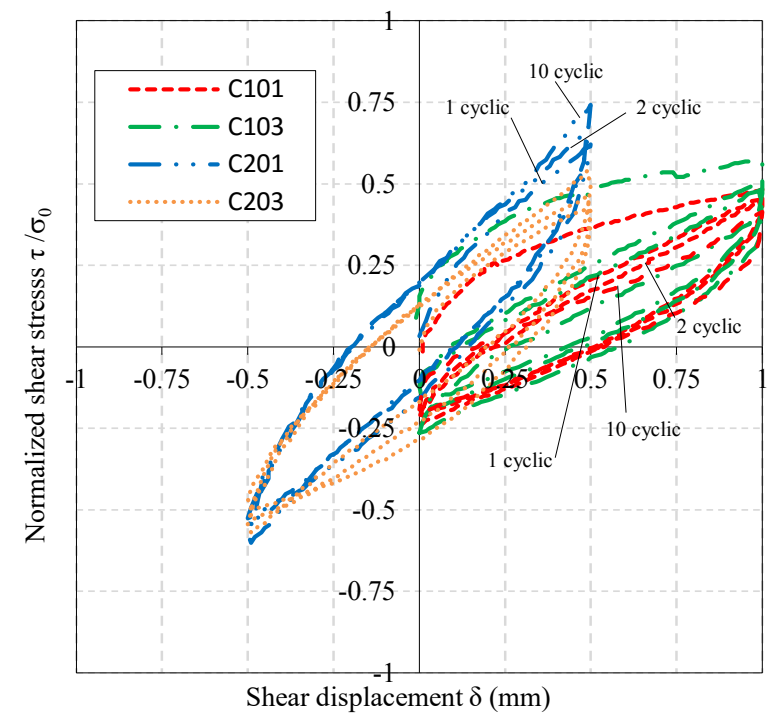

Fig. 12. Cyclic shear stress - displacement behaviour under one-sided and two-sided shearing for the overconsolidated area

\section{Conclusions}

Through this paper, the mechanical behaviour of unsaturated undisturbed black volcanic ash soils was 
investigated using a constant volume direct shear box apparatus. A series of static and cyclic tests were conducted. Also, X-ray fluorescence analysis and Scanning Electron Microscope (SEM) has been done. The main conclusions are as follows:

1. Under static shearing, unsaturated sample exhibits a higher the apparent cohesion and friction angle in comparison to the saturated sample condition.

2. The normalized vertical stress under one-sided cyclic shearing in both overconsolidated and the normally consolidated samples rapidly reduced at the beginning of shearing.

3. The normalized shear stress of the unsaturated undisturbed sample was found to be larger than that of the saturated sample under both one-sided and twosided cyclic shearing. This can be attributed to the influence of the matric suction contribution in the total shear strength of soils.

4. The chemical content of black volcanic ash soil results $\mathrm{SiO}_{2}, \mathrm{Al}_{2} \mathrm{O}_{3}, \mathrm{Fe}_{2} \mathrm{O}_{3}$ accounts for as high as about $93 \%$. It is known that these three are the main components of a substances called allophane.

5. Shearing changes the microstructure by breaking down the particles. For the overconsolidated sample, particles of soil more severe damage than the normally consolidated sample from SEM results.

\section{References}

1. Y. Kitazono, A. Suzuki, M. Kajiwara, S. Aramaki, Soils Found, 27, 23 (1987)

2. N.S. Mshana, A. Suzuki, Y. Kitazono, Soils Found, 33, 74 (1993)

3. Japan Soil Inventory, National Agriculture Industry Research Organization, (2016)

4. Y. Yamauchi, Kyushu University Press, (1983) (In Japanese)

5. T. Mukonoki, K. Kasama, S. Murakami, H. Ikemi, R. Ishikura, T. Fujikawa, N. Yasufuku, Y. Kitazono, Soils Found, 56, 947 (2016)

6. W.O. Sumartini, H. Hazarika, T. Kokusho, S. Ishibasi, D. Matsumoto, B. Chaudhary, Lwlnd. Tech. Intrnal, 14, 237 (2018)

7. T. Kiyota, T. Ikeda, K. Konagai, M. Shiga, Int. J. Geoeng. Case. H, 4, 78 (2017)

8. G. Chiaro, M. Umar, T. Kiyota, C. Massey, Geotech. Earthq. Eng. Soil Dynmcs. V GSP 293, 98 (2018)

9. Y. Miyabuchi, J. Geogr, 125, 421 (2016)

10. A. Alowaisy, N. Yasufuku, R. Ishikura, R. Yamamoto, M. Hatakeyama, JSCE (2017)

11. J.H. Atkinson, D. Richardson, Geotechnique, 37, 393 (1987)
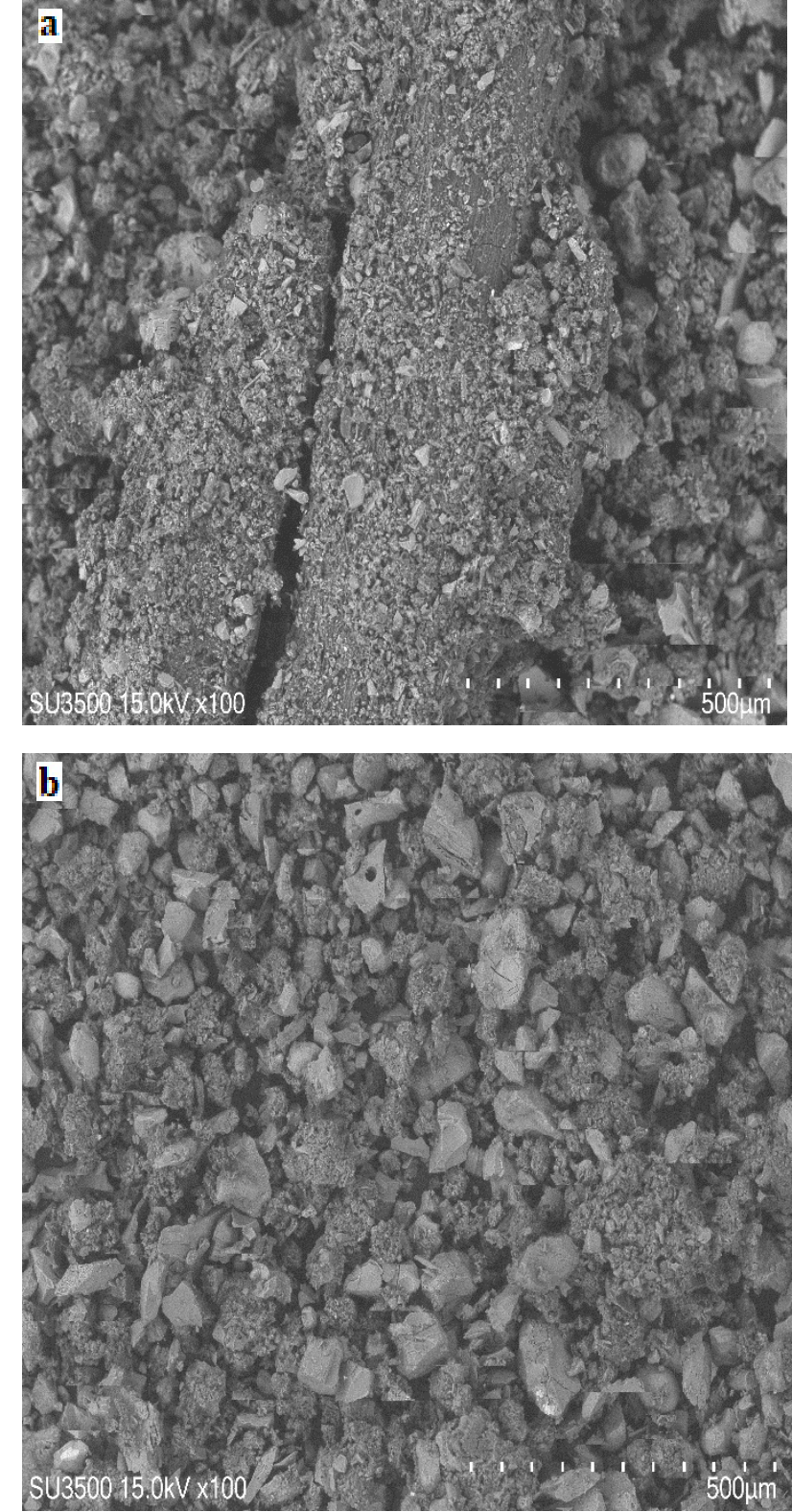

Fig. 13. SEM results of black volcanic ash soil. a) After shearing in the overconsolidated sample. b) After shearing in the normally consolidated sample.

12. F.Q. Bai, S.H. Liu, Geotech. Test. J, 35, 451 (2010)

13. S. Atsumi, J-Stage, 12, 75 (1972) (In Japanese)

14. P.W. Wayne, J. Geotech. Eng, 110, 1511 (1984)

15. M. Suzuki, T. Yamamoto, K. Kitamura, K. Nakamori, J. Fukuda, Yamaguchi University School of Engineering, 53, 35 (2003) (In Japanese)

16. H. Matsuda, A.P. Hendrawan, R. Ishikura, S. Kawahara, Soils Found, 51, 873 (2011)

17. K. Kasama, S. Yamagata, H. Tanaka, Z. Furukawa, N. Yasufuku. J-Stage, 13, 171 (2018) (In Japanese)

18. A.F. Cabalar, K. Dulundu, K. Tuncay, J. Eng. Geol, 156, 92-102 (2013)

19. J.K, Mitchell, Fundamentals of Soil Behaviour, (1993) 